\title{
Visualization Analysis on Collaborative Network and Research Hot-Spot for Aerospace Engineering Subject
}

\author{
Mei Xiuxiu ${ }^{1, a}$, Qin Ping ${ }^{2, b}$, Li Xiaotao ${ }^{3, c}$ \\ ${ }^{123}$ Library, Nanjing University of Aeronautics and Astronautics, Nanjing, 210000,China \\ ae-mail: meixiuxiu_nuaa@126.com, be-mail:qplib@nuaa.edu.cn, ce-mail:Ixtlib@nuaa.edu.cn
}

Keywords: Visualization; Social Network; Collaborative Networks; Two-Mode Network

\begin{abstract}
Based on SCIE and DII documents (2006-2015) and social network analysis, this paper analyzes one-mode network structural characteristics of co-authoring, institutional cooperation and patent owner cooperation, then constructs two-mode network by the $\mathrm{N}$-Cliques factions division and author keyword coupling analysis, via the visual tool NETDRAW. It finds 7 cooperative groups, different research hot-spots, Matthew cooperative networks are present, there is a big difference between academic and patent cooperation networks.
\end{abstract}

\section{Introduction}

The State Council promulgated overall plan to promote construction of world-class universities and first-class disciplines[1], and insisted on taking disciplines as the basis to support higher education institutions to optimize disciplinary structure in 2015. One of the effective ways to improve level of discipline development is to fully understand overall cooperation network of the subject. Many scholars have carried out research on subject cooperation network. Qiu Junping carried out network research of discipline cooperation[2]. Chai Yue built a university network of disciplines and characteristics of analysis[3]. Sung-Seok K[4],Hyunseok P[5],Kumar S[6] mainly concentrated in regional or national academic cooperation network research for the development of scientific research strategy. Those papers have not used multi-type literature data source to reveal cooperation networks of the engineering disciplines. Above all, based on the SCIE and DII patent data sources, this paper constructs a two-mode network by using social network analysis method and the coupling analysis of author keywords.

\section{Data Sources and Research Methods}

The paper selects the core collection of Web of Science data, and retrieval type is WC=(ENGINEERING AEROSPACE), "WC" represents the subject type, aerospace science and technology subject corresponds to "ENGINEERING AEROSPACE". Patent data select Derwent patent database and retrieval type is IP $=($ B64B-001/00 OR B64C-001/00 ... OR B64G-099/00), "IP" refers to IPC number, the international patent classification number. This subject corresponds to IPC classification is No. B64 (AIRCRAFT; AVIATION; COSMONAUTICS). 46,311 records were retrieved.

Social network analysis (SNA) comes from matrix theory and graph theory in field of mathematics[7]. Social network refers to a set of social actors acting as nodes and relationships among them, revealing nodes on behalf of structural changes in actors.

\section{Network Structure Analysis}

Degree centrality measures location and power of a node in the network. If an actor is directly linked to many other actors, then the actor is in a central position. The co-occurrence matrix is loaded into the Ucinet software and along Network $\rightarrow$ Centrality $\rightarrow$ Degree path. Degree centrality results are shown in Table 1. 
Table 1 Collaborative network degree centrality measurement results

\begin{tabular}{|c|c|c|c|c|c|c|}
\hline Number & Author & NrmDegree & Organization & NrmDegree & Patentee & NrmDegree \\
\hline 1 & BAO, WEN & 0.826 & RAS & 1.469 & AIRBUS & 1.693 \\
\hline 2 & CHANG, JUNTAO & 0.794 & NASA & 1.431 & AIRBUS-France & 1.407 \\
\hline 3 & MULDER, $\mathrm{M}$. & 0.689 & MIT & 1.376 & AIRBUS-Germany & 1.400 \\
\hline 4 & VAN PAASSEN, M. M. & 0.646 & DLR & 1.196 & European helicopter & 0.589 \\
\hline 5 & $\begin{array}{c}\text { QUARTA, } \\
\text { ALESSANDRO A. }\end{array}$ & 0.508 & ESA & 0.894 & $\begin{array}{c}\text { European } \\
\text { helicopter-France }\end{array}$ & 0.518 \\
\hline 6 & MENGALI, GIOVANNI & 0.498 & $\begin{array}{c}\text { USAF } \\
\text { JAPAN AEROSP }\end{array}$ & 0.604 & Boeing & 0.501 \\
\hline 7 & LI, JUNFENG & 0.477 & $\begin{array}{l}\text { EXPLORAT } \\
\text { AGCY }\end{array}$ & 0.563 & AIRBUS-Helicopter & 0.345 \\
\hline 8 & YU, DAREN & 0.413 & $\begin{array}{l}\text { GEORGIA INST } \\
\text { TECHNOL }\end{array}$ & 0.442 & Thales Group & 0.296 \\
\hline 9 & MULDER, J. A. & 0.392 & $\begin{array}{c}\text { Indian Institute of } \\
\text { Technology }\end{array}$ & 0.42 & $\begin{array}{c}\text { Safran } \\
\text { Group-Aircelle }\end{array}$ & 0.165 \\
\hline 10 & HUANG, WEI & 0.381 & CALTECH & 0.392 & AIRBUS-English & 0.151 \\
\hline
\end{tabular}

As can be seen from Table 1, Prof. Bowen of Harbin Institute of Technology has the largest degree centrality, the team composed by Chang Juntao and Yu Daren is at the center of the author co-authoring network. The Russian Academy of Sciences and Airbus dominate their respective networks. Despite the prominence of Chinese researchers in individual co-authorship network, Chinese organizations and patentees are not at the center of the network. The overall network centralization of the three cooperative networks is less than $2 \%$, indicating that there are a large number of authors, organizations, and patentees in the three networks have no cooperation.

Betweenness centrality measures the ability of a node controlling other nodes. If a node is between many other two points on the path in the network, it can influence the network by controlling the transmission of information[8]. Betweenness centrality is analyzed along Network $\rightarrow$ Centrality $\rightarrow$ Freeman Betweenness $\rightarrow$ Nodes Betweeness path. The analysis results are shown in Table 2.

Table 2 Results of cooperative network betweenness centrality measurement

\begin{tabular}{|c|c|c|c|c|c|c|}
\hline Number & Author & $\begin{array}{l}\text { nBetwe } \\
\text { e-nness }\end{array}$ & Organization & $\begin{array}{c}\text { nBetwee } \\
\text {-nness }\end{array}$ & Patentee & nBetwee-nness \\
\hline 1 & SCHEERES, DANIEL J. & 2.028 & RAS & 17.269 & ESA-France & 1.266 \\
\hline 2 & ALFRIEND, KYLE T. & 1.497 & MIT & 9.853 & AIRBUS & 1.169 \\
\hline 3 & VADALI, SRINIVAS R. & 1.457 & NASA & 8.96 & $\begin{array}{l}\text { General Electric } \\
\text { Company }\end{array}$ & 1.112 \\
\hline 4 & YAMAKAWA, HIROSHI & 1.284 & ESA & 4.247 & AIRBUS-Germany & 0.716 \\
\hline 5 & SCHAUB, HANSPETER & 1.263 & USAF & 2.949 & AIRBUS-France & 0.674 \\
\hline 6 & SANKAR, LAKSHMI N. & 1.23 & $\begin{array}{c}\text { Chinese Academy } \\
\text { of Sciences }\end{array}$ & 2.227 & European helicopter & 0.337 \\
\hline 7 & BUTCHER, ERIC A. & 1.229 & $\begin{array}{l}\text { Beihang } \\
\text { University }\end{array}$ & 2.149 & $\begin{array}{c}\text { United Technologies } \\
\text { Corporation }\end{array}$ & 0.2 \\
\hline 8 & MORTARI, DANIELE & 1.219 & $\begin{array}{l}\text { Cranfield } \\
\text { University }\end{array}$ & 2.100 & $\begin{array}{l}\text { Kawasaki Heavy } \\
\text { Industries Limited }\end{array}$ & 0.2 \\
\hline 9 & BAEDER, JAMES D. & 1.183 & $\begin{array}{c}\text { GEORGIA INST } \\
\text { TECHNOL }\end{array}$ & 1.846 & HISPANO SUIZA & 0.169 \\
\hline 10 & CRASSIDIS, JOHN L. & 1.136 & $\begin{array}{c}\text { University of } \\
\text { Michigan }\end{array}$ & 1.748 & $\begin{array}{c}\text { European } \\
\text { helicopter-France }\end{array}$ & 0.168 \\
\hline
\end{tabular}

Co-Author network centralization=1.90\%; Co-Organization network centralization=16.81\%; Co-Patentee network centralization=1.19\%

As can be seen from Table 2, individual scholars DANIEL J. has the largest betweenness centrality, and nine of the top ten scholars belong to American universities. Europe and the United States academy and airlines are at the core position, controlling resources flows. Chinese Academy of Sciences and Beihang University are among the forefront, which suggests their impacts on other organizations' co-existing. Co-organization network centralization is $16.81 \%$, much higher than the patentee' (1.19\%), which indicates the control abilities of academic research institutions in cooperative resource is much stronger than the patentees'. 
Closeness centrality measures the ability of a node is not controlled by other nodes. If a node is connected to many other nodes in the network by a relatively short path, it has a relatively high closeness centrality[9]. Closeness centrality is performed along Network $\rightarrow$ Centrality $\rightarrow$ Closeness path. The analysis results are shown in Table 3.

Table 3 Results of cooperative network closeness centrality measurement

\begin{tabular}{|c|c|c|c|c|c|c|}
\hline Number & Author & nCloseness & Organization & nCloseness & Patentee & nCloseness \\
\hline 1 & SCHEERES, DANIEL J. & 0.536 & RAS & 77.928 & AIRBUS & 1.04 \\
\hline 2 & ALFRIEND, KYLE T. & 0.536 & MIT & 73.617 & AIRBUS-France & 1.04 \\
\hline 3 & BUTCHER, ERIC A. & 0.535 & NASA & 72.385 & AIRBUS-Germany & 1.039 \\
\hline 4 & VADALI, SRINIVAS R. & 0.535 & ESA & 65.283 & EADS & 1.039 \\
\hline 5 & SCHAUB, HANSPETER & 0.535 & USAF & 62.681 & DLR & 1.038 \\
\hline 6 & CRASSIDIS, JOHN L. & 0.535 & DLR & 60.702 & AIRBUS-English & 1.038 \\
\hline 7 & JUNKINS, JOHN L. & 0.535 & $\begin{array}{l}\text { University of } \\
\text { Michigan }\end{array}$ & 59.45 & $\begin{array}{l}\text { General Electric } \\
\text { Company }\end{array}$ & 1.038 \\
\hline 8 & SINGLA, PUNEET & 0.535 & $\begin{array}{l}\text { GEORGIA INST } \\
\text { TECHNOL }\end{array}$ & 59.45 & AIRBUS-helicopter & 1.038 \\
\hline 9 & MORTARI, DANIELE & 0.535 & CALTECH & 59.45 & $\begin{array}{c}\text { European } \\
\text { helicopter-France }\end{array}$ & 1.038 \\
\hline 10 & LEE, DAERO & 0.535 & $\begin{array}{l}\text { University of } \\
\text { Colorado }\end{array}$ & 57.475 & European helicopter & 1.038 \\
\hline
\end{tabular}

Co-Author network centralization and Co-Patentee network centralization can't be calculated; Co-Organization network centralization=52.92\%;

Nodes, both appearing in table 2 and table 3, aren't controlled by the network control the overall cooperative network resources, they are network bridges. If these nodes leave suddenly, it will have a huge impact on information exchange of the whole cooperative network. As there are no links between nodes of various groups, co-author network centralization can't be calculated. The reason why co-patentee network centralization can't be calculated is the existence of isolated points in the network. The special nature of the technical knowledge contained in the patent makes most patentees applying for patents alone without cooperation with other patentees.

\section{Cooperation Groups and Research Hotspots Visualization}

The co-author network is divided into two cooperating groups, and the hot-spot knowledge map is shown in Fig.1.

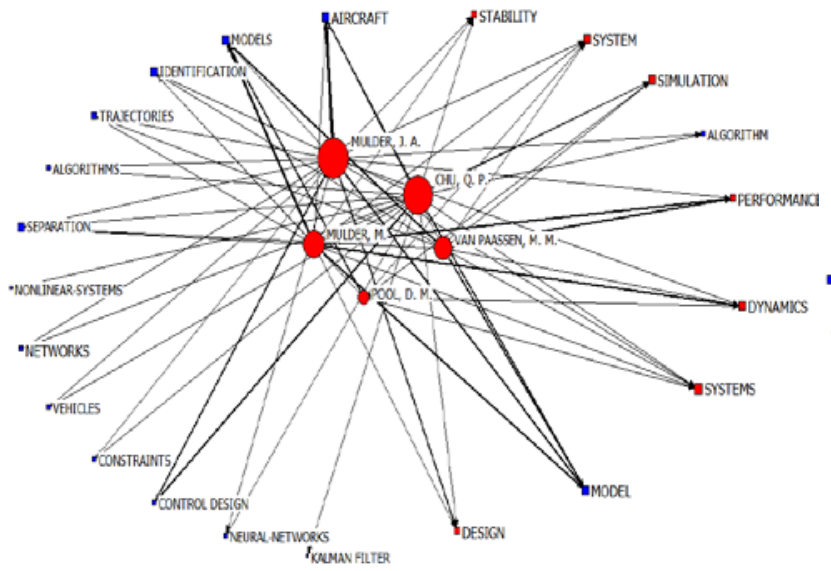

(a) Group 1

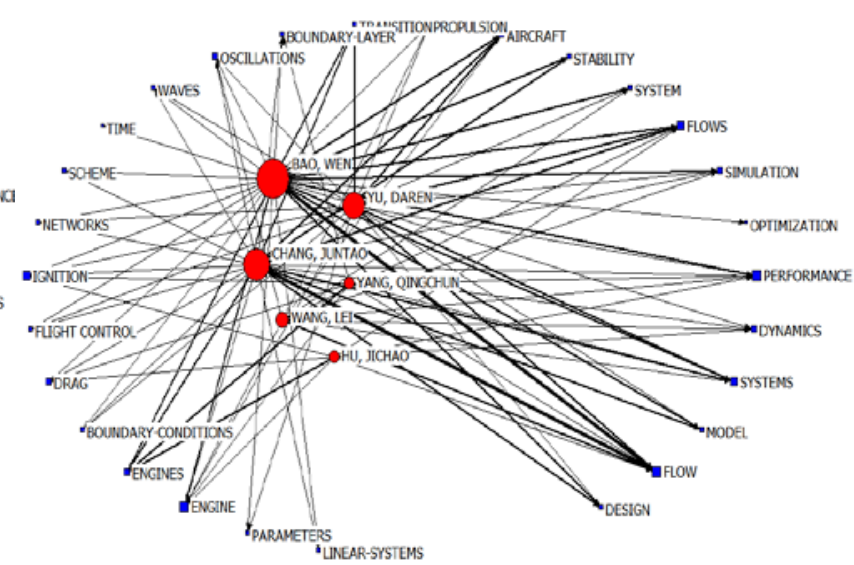

(b) Group 2

Figure 1 Co-author network research hot-spot knowledge map

As shown in Fig.1 (a), Mulder J A and Chu Q P belong to Delft University of Technology are the most important nodes in group 1 . This team proposed a low-cost power system, by simulating in the high-end simulator, removing system platform constraints composed of platform filter, time delay and noise characteristics, so as to identify pilots' perception and control behavior. As shown in Fig.1 (b), Professor Bao Wen and Chang Juntao are core characters in group 2. The group's representative research is hypersonic cruise missiles, trans-atmospheric vehicles and reusable space propeller 
thrusters, and recently create a unique cooling scheme to solve limited heat source of low-temperature heat.

The co-organization network is divided into two cooperating groups, and the hot-spot knowledge map is shown in Fig.2.

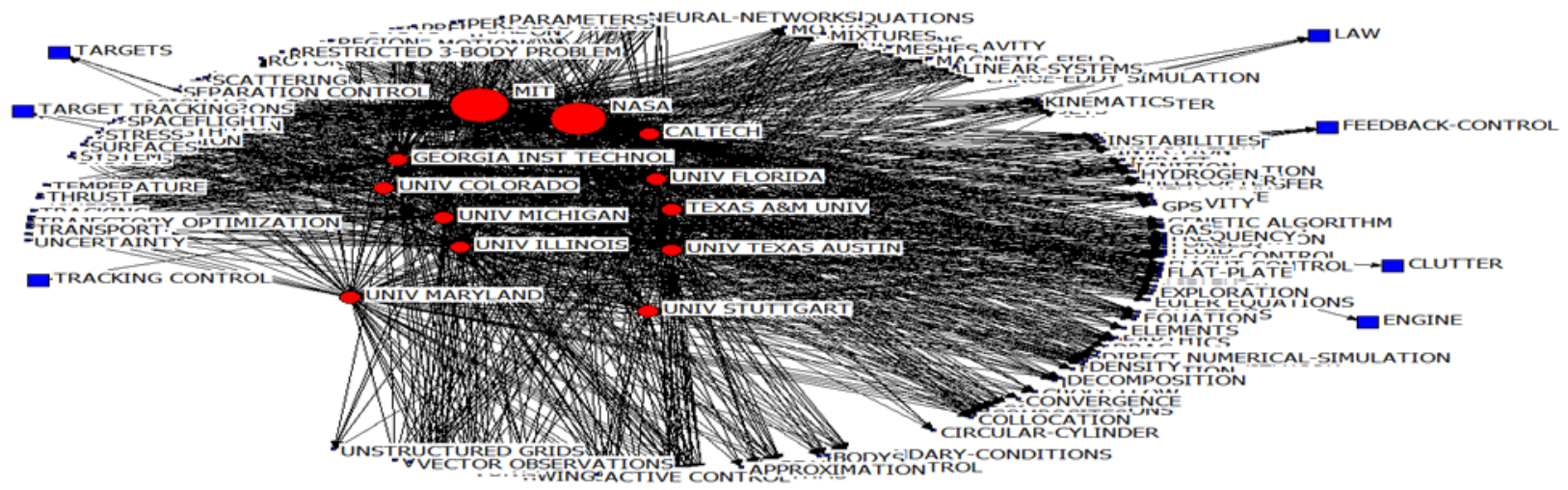

(a) Group 1

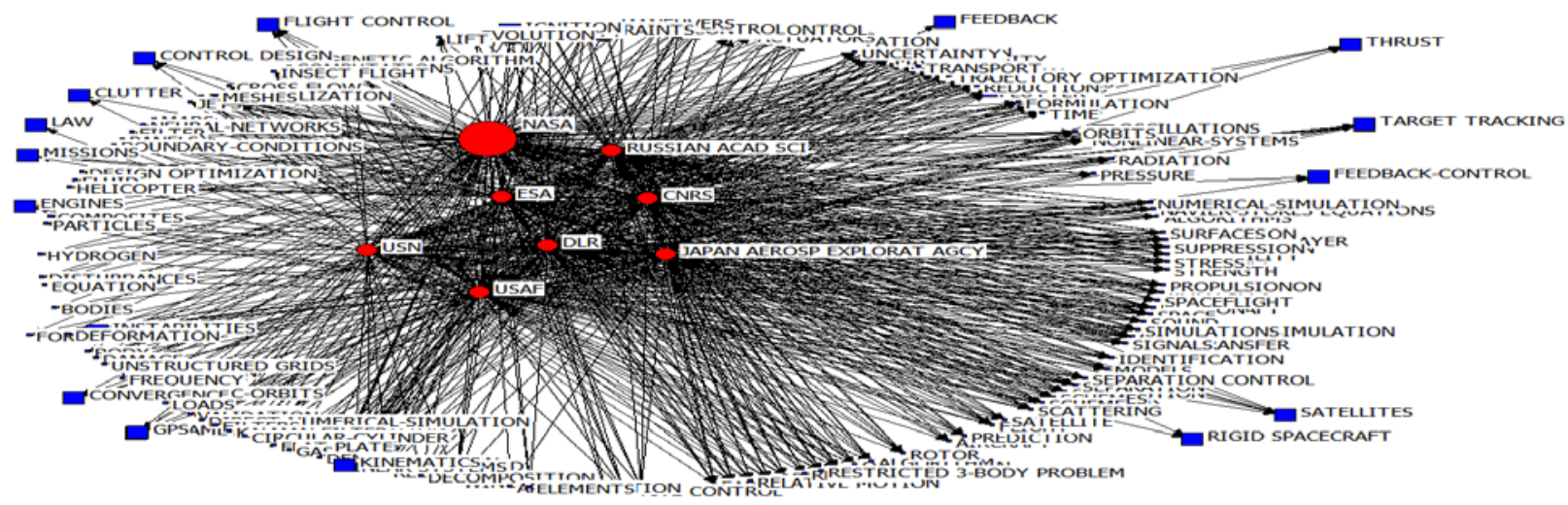

(b) Group 2

Figure 2 Co-organization network research hot-spot knowledge map

As shown in Fig.2 (a) and Fig.2 (b), group 1 is an American academic institution group centered on NASA and MIT, and group 2 is a research institution group taking NASA as the core. The main research direction of two groups above is space station, target tracking and monitoring of aircraft feedback. Although ESA, Japan Aerospace Research Institute and RAS are main members of group 2, the research content is United States leading space station frontier field. The reason of research knowledge units focusing on tracking and monitoring is the US space station has entered into a stable development stage. The Planetary Defense Coordination Department has been set up to track and monitor space stations and celestial bodies in the universe.

The co-patentee network is divided into three cooperating groups, and the hot-spot knowledge map is shown in Fig.3.

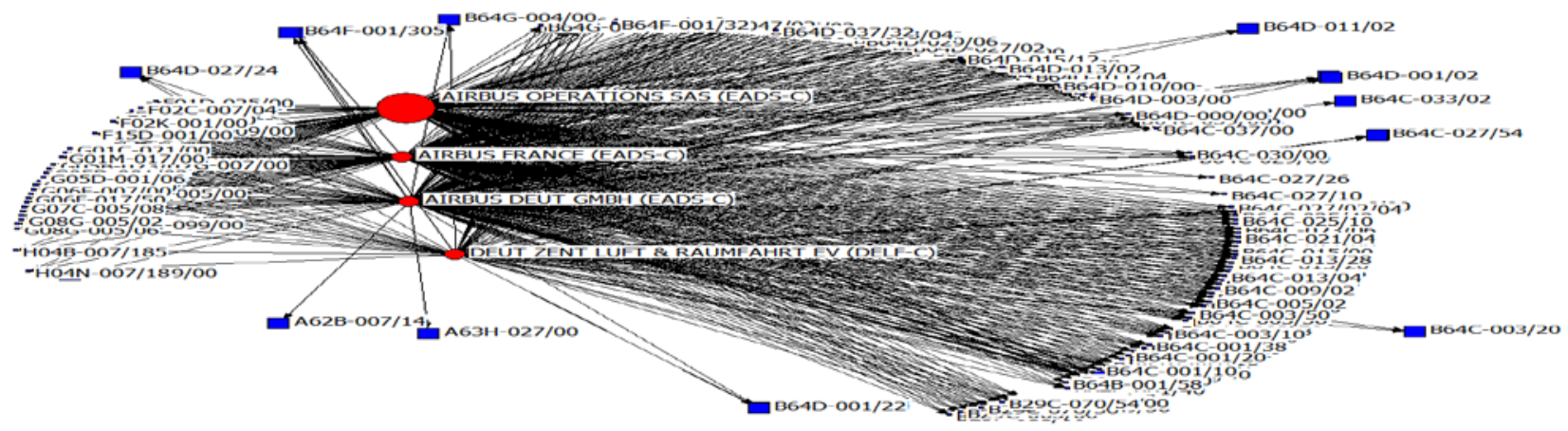

(a) Group 1 


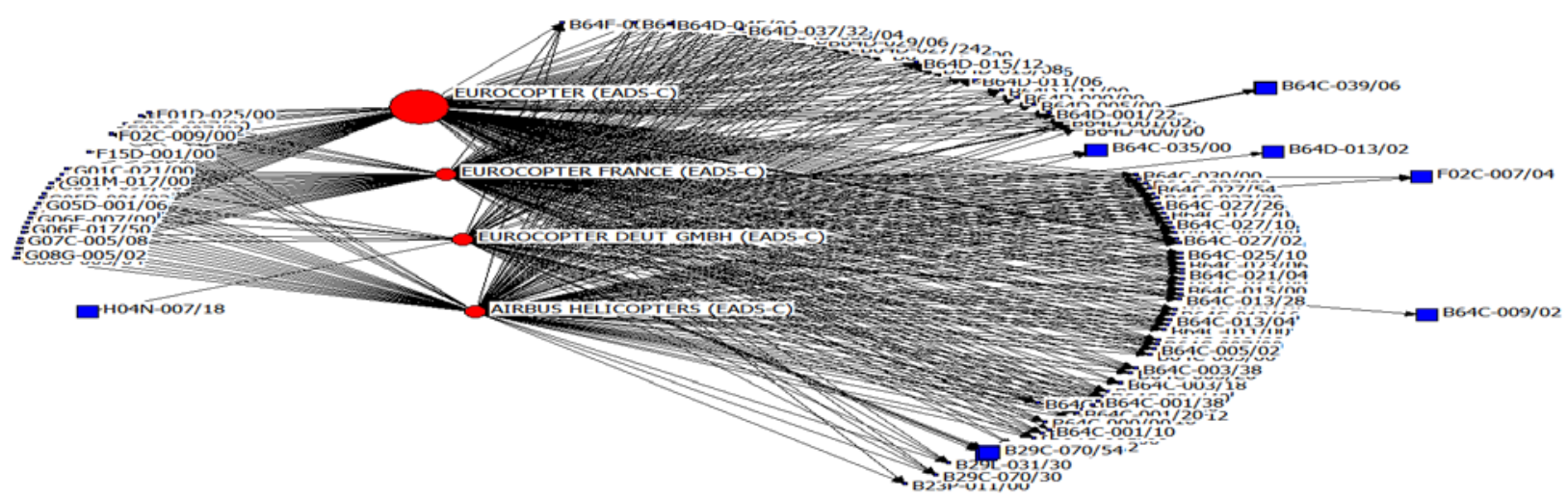

(b) Group 2

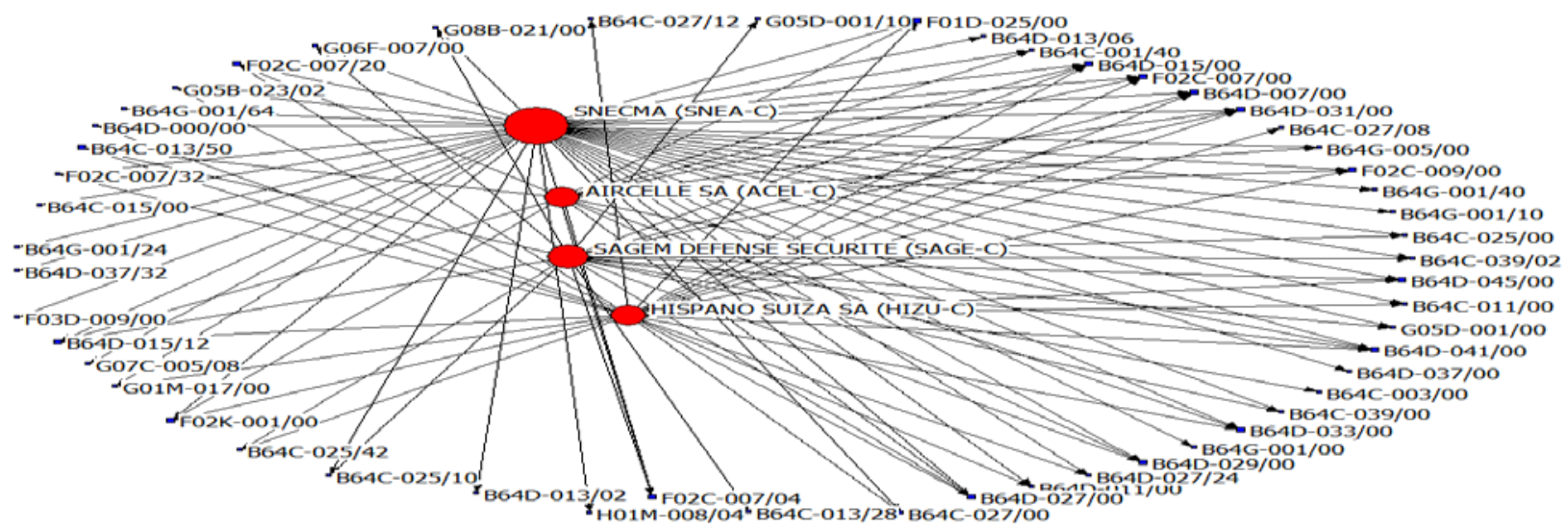

(c) Group 3

Figure 3 Co-patentee network research hot-spot knowledge map

From Fig.3, Group 1 is Airbus corporation, and its main research directions are helicopter, aircraft and auxiliary equipment related to the production line of Airbus. Group 2 is European Helicopter corporation and its research directions are helicopter and aircraft models as well as auxiliary equipment related to the European Helicopter production line. Group 3 is composed of subsidiaries of Safran Group. IPC nodes' size is uniform, thus technical points are evenly distributed. Safran is a high-tech multinational group in the aerospace industry. Subsidiary Snecma' research direction is the development and production of aircraft power plant. Subsidiary Aircelle whose research direction embodied in the engine system and engine room system, has main technical points including air thrust, heat flow devices, emergency braking system. Safran Electronics Defense's research direction is reflected in the field of aeronautic optoelectronics and key software, with patented technologies in European optoelectronics, helicopter unmanned aerial vehicle control systems and inertial navigation systems (INS). Subsidiary HISPANO SUIZA SA focuses on power-train systems, which are distributed in information technology, new materials, manufacturing processes, innovative design.

\section{Results and Discussion}

Based on the above analysis, specific differences between aerospace science and technology journals and patent cooperation networks are shown in Table 4. 
Table 4 Comparative Analysis of Aerospace Engineering Subject Periodicals and Patent Cooperation Networks

\begin{tabular}{|c|c|c|c|}
\hline Contrast & Feature & Periodicals Cooperation Networks & Patent Cooperation Networks \\
\hline & $\begin{array}{c}\text { cooperation } \\
\text { degree }\end{array}$ & Very high, mature stage & Lower, primary stage \\
\hline \multirow[t]{4}{*}{$\begin{array}{l}\text { Different } \\
\text { points }\end{array}$} & $\begin{array}{c}\text { Network } \\
\text { density }\end{array}$ & Lower, more contact and loose & Higher, less contact and close \\
\hline & $\begin{array}{l}\text { Cooperation } \\
\text { model }\end{array}$ & Geo-based, industry-based supplement & Kinship-based \\
\hline & $\begin{array}{l}\text { Representati } \\
\text { ve group }\end{array}$ & $\begin{array}{l}\text { Massachusetts Institute of Technology as the } \\
\text { core of the US academic institutions, NASA as } \\
\text { the core of the National Aeronautics and Space } \\
\text { Administration }\end{array}$ & $\begin{array}{c}\text { Airbus, European helicopters, Safran Group and } \\
\text { other parent companies as the core, subsidiaries } \\
\text { have their own strengths of large airlines }\end{array}$ \\
\hline & $\begin{array}{c}\text { Research } \\
\text { area }\end{array}$ & $\begin{array}{c}\text { Earth Sciences, Space Science, Monitoring and } \\
\text { Tracking of Space Stations and Celestial Bodies, } \\
\text { Emphasis on Simulation, Model Optimization, } \\
\text { etc. Space Exploration Area }\end{array}$ & $\begin{array}{l}\text { Defense technology, commercial aircraft, } \\
\text { helicopters, aerospace, military transport and } \\
\text { combat aircraft and related services, with a focus } \\
\text { on technology areas such as manufacturing, } \\
\text { service and maintenance }\end{array}$ \\
\hline $\begin{array}{c}\text { Identical } \\
\text { points }\end{array}$ & $\begin{array}{c}\text { Matthew } \\
\text { Effect }\end{array}$ & \multicolumn{2}{|c|}{$\begin{array}{l}\text { Scale-free network characteristics, a few nodes have a large number of connections, most nodes are } \\
\text { connected very little }\end{array}$} \\
\hline
\end{tabular}

There are great differences between journals and patent literature-based cooperative networks in the aerospace engineering subject. It is believed that the cooperation should be aimed at the differences, promote the integration of academic research and applied research, so as to promote development of the subject and the level of aerospace industry.

\section{References}

[1] http: //www.gov.cn/zhengce/content/2015-11/05/content_10269.htm.

[2] Niu Fengao, Qiu Junping.Study on International Cooperation of China 's Scientific Research Based on the Cooperation Networks and Journals Distribution [J]. Information Science, 2015, 5: 111-118.

[3] Chai Yue, Liu Chen, Wang Xianwen. The Construction and Characteristic Analysis of Scientific Research Cooperation Network in Universities in China Based on the Data of "211" University [J] .Library and Information Work, 2015, 2: 82-88.

[4] Sung-Seok K, Namuk K, Doyeon K, et al. Analyzing technology impact networks for R \& D planning using patents: combined application of network approaches[J]. Scientometrics, 2014, 10: 917-936.

[5] Hyunseok P, Janghyeok Y. Assessing coreness and intermediarity of technology sectors using patent co-classification analysis: the case of Korean national R \& D[J]. Scientometrics, 2014, 2: 853-890.

[6] Kumar, S, Jan, J M. Relationship between authors' structural position in the collaboration network and research productivity case of Indian earth scientists[J]. Program-Electronic Library and Information Systems, 2014, 4: 355-369.

[7] Scott. Social network analysis [M]. Chongqing: Chongqing University Press, 2007:7-13.

[8] Jiang Xin.Application of Social Network Analysis Method in Library and Information [M]. Beijing: Intellectual Property Press, 2015:46.

[9] Freeman L. C. Centrality in social networks: conceptual clarification [J]. Social Networks, 1979, 1: 215-239. 